Tropical Journal of Pharmaceutical Research April 2019; 18 (4): 823-828

ISSN: $1596-5996$ (print); 1596-9827 (electronic)

(C) Pharmacotherapy Group, Faculty of Pharmacy, University of Benin, Benin City, 300001 Nigeria.

\title{
Effect of aqueous leaf extract of Thunbergia laurifolia on alcohol-induced liver injury in rats
}

\author{
Sarawoot Palipoch ${ }^{1 *}$, Phanit Koomhin ${ }^{1}$, Chuchard Punsawad', Prasit \\ Suwannalert ${ }^{2}$ \\ ${ }^{1}$ School of Medicine, Walailak University, 222 Thaiburi, Thasala District, Nakhon Si Thammarat, 80161, ${ }^{2}$ Department of \\ Pathobiology, Faculty of Science, Mahidol University, 272 Rama VI Road, Ratchathewi District, Bangkok 10400, Thailand
}

*For correspondence: Email: spalipoch@hotmail.com, sarawoot.pa@wu.ac.th; Tel: +66 7567 2873; Fax: +66 75672807

Sent for review: 25 July 2018

Revised accepted: 14 March 2019

\begin{abstract}
Purpose: To investigate the antioxidant and anti-inflammatory effects of aqueous leaf extract of $T$. laurifolia against alcoholic liver injury in rats.

Methods: Male Wistar rats were administered either normal saline, ethanol (EtOH), normal saline with low or high dose $T$. laurifolia leaf extract (TL-LD or $T L-H D$ ), EtOH with $T L-L D$ or EtOH with $T L-H D$. Blood biochemical indices: hepatic malondialdehyde (MDA) levels, liver histopathology, hepatic cytochrome P450 2E1 (CYP2E1), nicotinamide adenine dinucleotide phosphate (NADPH) oxidase, and pro-inflammatory cytokines, including interleukin 1 beta (IL-1 $\beta$ ) and tumor necrotic factor alpha (TNF- $\alpha$ ) mRNA expressions, were determined using standard methods.

Results: The leaf extract of T. Laurifolia decreased hepatic MDA levels, improved liver pathology and down-regulated mRNA expressions of CYP2E1, NADPH oxidase and pro-inflammatory cytokinesin ethanol-treated rats.

Conclusion: These results demonstrate that aqueous extract of $T$. Laurifolia exerts hepatoprotective effect against alcoholic liver injury through a mechanism involving inhibition of oxidative stress and inflammation.
\end{abstract}

Keywords: Thunbergia laurifolia, Alcohol, Liver injury, Oxidative stress, inflammation, Protection

\begin{abstract}
This is an Open Access article that uses a fund-ing model which does not charge readers or their institutions for access and distributed under the terms of the Creative Commons Attribution License (http://creativecommons.org/licenses/by/4.0) and the Budapest Open Access Initiative (http://www.budapestopenaccessinitiative.org/read), which permit unrestricted use, distribution, and reproduction in any medium, provided the original work is properly credited.

Tropical Journal of Pharmaceutical Research is indexed by Science Citation Index (SciSearch), Scopus, International Pharmaceutical Abstract, Chemical Abstracts, Embase, Index Copernicus, EBSCO, African Index Medicus, JournalSeek, Journal Citation Reports/Science Edition, Directory of Open Access Journals (DOAJ), African Journal Online, Bioline International, Open-J-Gate and Pharmacy Abstracts
\end{abstract}

\section{INTRODUCTION}

The liver is the primary organ of ethanol metabolism. Chronic alcohol consumption results in alcohol-induced liver disease (ALD). In ALD, the altered capacity of hepatocytes to cope with environmental toxins, and their altered oxidationreduction potential result in liver injury [1]. The hallmarks of ALD are steatosis, steatohepatitis, fibrosis, and more severe forms including cirrhosis and hepatocellular carcinoma [2]. Oxidative stress and inflammation are critical factors in etiology of ethanol-induced liver damage [2]. Reactive oxygen species (ROS) are implicated in the progression from hepatic steatosis to steatohepatitis and cirrhosis [3].

Previous studies have reported that ethanol exposure induced the expressions of cytochrome 
P450 2E1 (CYP2E1) and nicotinamide adenine dinucleotide phosphate (NADPH) oxidase, resulting in the production of ROS and other free radicals [4]. It is known that NADPH oxidase transfers an electron from NADPH to molecular oxygen to produce the superoxide radical $\left(\mathrm{O}_{2}{ }^{\circ}\right)$. A previous study demonstrated the involvement of NADPH oxidase 4 in early alcoholic liver injury and its regulation of the recruitment of inflammatory cells and production of proinflammatory cytokines [5].

Excessive alcohol consumption has been shown to increase hepatic translocation of gut-sourced endotoxin/lipopolysaccharide, resulting in activation of innate immune cells such as Kupffer cells and natural killer (NK)/NKT cells, and production of large amounts of ROS, proinflammatory cytokines [interleukin-1 (IL-1), tumor necrotic factor- $\alpha$ (TNF- $\alpha$ )] and ultimately, liver injury [6]. Inhibition of pro-inflammatory cytokines has been shown to accentuate recovery from alcoholic hepatitis [7].

Thunbergia laurifolia has long been described in Thai Traditional Medicine. Numerous studies have reported its various pharmacological effects in both in vitro and in vivo models [8,9]. It has been shown to exert hepatoprotective activity against ethanol-induced liver injury in primary cultures of rat hepatocytes and in rats. However, the mechanisms involved in these effects are still unknown.

Therefore, the present study was carried out to investigate the antioxidant and anti-inflammatory effects of $T$. laurifolia aqueous leaf extract against alcoholic liver injury in male Wistar rats, and the underlying mechanism(s).

\section{EXPERIMENTAL}

\section{Preparation of aqueous extract of $T$. laurifolia leaves}

Thunbergia laurifolia leaves were collected from a location at Nakhon Si Thammarat province, Thailand. The leaves were washed several times in running water, dried at $60^{\circ} \mathrm{C}$ for $48 \mathrm{~h}$ in a hot air oven, and ground to powder using a blender. The leaf powder $(10 \mathrm{~g})$ was extracted with $100 \mathrm{~mL}$ of boiling water for $48 \mathrm{~min}$, and the aqueous extract was lyophilized in a freeze dryer (Eyela, Tokyo, Japan). The powder was preserved at $-80^{\circ} \mathrm{C}$ until used.

\section{Experimental animals and treatments}

Approval for the animal procedures were received from the Animal Ethics Committee,
Walailak University (certification no. 005/2015). The study was carried out in line with the Guide for the Care and Use of Laboratory Animals from the National Research Council [10].

Twenty-four male Wistar rats (Rattus norvegicus) aged 12 weeks were obtained from the Division of Animal House, Faculty of Science, Prince of Songkla University, Thailand. The rats were maintained in stainless steel cages under constant conditions of temperature $\left(23 \pm 2^{\circ} \mathrm{C}\right)$, relative humidity $(50-60 \%)$ and lighting (12 h light/12 $\mathrm{h}$ dark cycle). Before the experiment, the rats were provided free access to standard commercial feed and distilled water.

The rats were randomly divided into six groups (4 rats per group): rats gavaged with normal saline once a day for 10 weeks (control group); rats gavaged with ethanol ( $30 \% \mathrm{v} / \mathrm{v}$ in saline, $4 \mathrm{~g} / \mathrm{kg}$ ) once a day for 10 weeks (EtOH group); rats gavaged with normal saline once a day for 10 weeks and then gavaged with low dose $T$. laurifolia leaf extract $(100 \mathrm{mg} / \mathrm{kg})$ once a day from weeks 5-10 (TL-LD group); rats gavaged with high dose $T$. laurifolia leaf extract (200 $\mathrm{mg} / \mathrm{kg}$ ) once a day from weeks 5 - 10 (TL-HD group); and rats gavaged with low dose $T$. laurifolia leaf extract $(100 \mathrm{mg} / \mathrm{kg})$ once a day at weeks 5-10 ( $\mathrm{EtOH}+\mathrm{TL}-\mathrm{HD}$ group); rats gavaged with ethanol (30\% v/v in saline, $4 \mathrm{~g} / \mathrm{kg}$ ) once a day for 10 weeks, and rats gavaged with high dose $T$. laurifolia leaf extract $(200 \mathrm{mg} / \mathrm{kg})$ once a day at weeks 5 - 10 (EtOH + TL-HD group). The rats were euthanized with thiopental sodium overdose (100 mg/kg body weight) anesthesia. The abdominal cavities were then opened, and the livers were excised. Peripheral blood was taken from the heart of each rat.

\section{Biochemical analysis}

The blood samples were centrifuged at $3000 \mathrm{rpm}$ for $5 \mathrm{~min}$. Sera were collected for determination of the levels of alanine aminotransferase (ALT), aspartate aminotransferase (AST), triglycerides and total protein using Chemistry Analyzer (Switzerland).

\section{Determination of hepatic MDA levels}

A $50 \mathrm{mg} / \mathrm{mL}$ liver homogenate was prepared by homogenizing liver sections on ice in phosphate buffered saline containing $1 \mathrm{X}$ butylated hydroxytoluene. The homogenate was centrifuged at $10,000 \times \mathrm{g}$ for $5 \mathrm{~min}$, and MDA was assayed in the supernatant using OxiSelect ${ }^{\text {TM }}$ TBARS Assay Kit (cat no. STA-330, Cell Biolabs, San Diego, CA, USA) in accordance with the manufacturer's protocol. 


\section{Histopathology}

Fresh liver sections were fixed in $10 \%$ neutral buffered formalin solution, processed for light microscopy and embedded in paraffin. Sections were sliced and subjected to hematoxylin and eosin $(H$ \& $E)$ staining in line with standard procedures.

\section{Determination of expressions of hepatic CYP2E1, NADPH oxidase, IL-1 $\beta$, and TNF- $\alpha$ mRNA}

Hepatic total RNA was extracted using an RNeasy Mini Kit (Qiagen, Germany). The content and purity of the RNA were measured using UV spectrophotometry. Reverse transcription and PCR were performed for amplification of the genes. The thermal cycling conditions were set up with an initial denaturation step at $95{ }^{\circ} \mathrm{C}$ for $15 \mathrm{~min}$, and at $94^{\circ} \mathrm{C}$ for $1 \mathrm{~min}$. The second step included annealing of primer at $65^{\circ} \mathrm{C}$ for $1 \mathrm{~min}$, while the third step involved an extension at 72 ${ }^{\circ} \mathrm{C}$ for $1 \mathrm{~min}$. The final step was elongation at 72 ${ }^{\circ} \mathrm{C}$ for $10 \mathrm{~min}$. The sequences of the primers used are shown in Table 1.

The DNA samples were loaded into $2 \%$ gel agarose. After staining with ethidium bromide, the gel was visualized with an UV transilluminator. The amount of PCR product was detected using GeneTools software with image analysis (Syngene, Frederick, MD, USA).

\section{Statistical analysis}

Results are expressed as mean \pm standard error of the mean (SEM). Differences between groups were determined using one-way analysis of variance (ANOVA). Post hoc testing was performed for group comparisons using the Least Significant Difference (LSD) test. Values of $p<$ 0.05 were considered significant.

\section{RESULTS}

Effect of $T$. laurifolia aqueous leaf extract on liver enzymes, triglycerides, total protein and MDA levels

As shown in Figure 1, rats gavaged with ethanol once a day for 10 weeks (EtOH group) had significantly higher serum levels of AST ( $p<$ $0.05)$ and ALT $(p<0.001)$ than rats in the control group. Moreover, the levels of triglycerides and total protein were significantly higher $(p<0.001$, $p<0.05$, respectively) in the $\mathrm{EtOH}$ group than in the control group. There were no significant differences in plasma levels of liver enzymes, triglycerides and total protein between rats gavaged with $100 \mathrm{mg} / \mathrm{kg}$ (TL-LD group) or 200 $\mathrm{mg} / \mathrm{kg}$ (TL-HD group) of $T$. laurifolia leaf extract once a day from weeks $5-10$, and rats in the control group. Rats gavaged with ethanol once a day for 10 weeks, and low dose of $T$. laurifolia leaf extract once a day from weeks $5-10$ (EtOH+TL-LD group) had significantly decreased levels of AST $(p<0.001)$, ALT $(p<0.001)$, triglycerides $(p<0.05)$ and total protein $(p<$ 0.05 ), when compared with rats in the $\mathrm{EtOH}$ group.

In contrast, rats gavaged with ethanol and high dose of $T$. laurifolia leaf extract ( $\mathrm{EtOH}+\mathrm{TL}-\mathrm{HD}$ group) had significantly decreased levels of AST $(p<0.001)$, ALT $(p<0.001)$, triglycerides $(p<$ $0.001)$ and total protein $(p<0.05)$, relative to rats in the EtOH group. Rats in the EtOH group showed significantly elevated MDA levels, when compared to rats in the control group $(p<0.05)$ (Figure $1 \mathrm{E}$ ), while rats in the $\mathrm{EtOH}+\mathrm{TL}-\mathrm{LD}$ and the $\mathrm{EtOH}+\mathrm{TL}-\mathrm{HD}$ groups had significantly decreased levels of MDA $(p<0.05)$, compared to rats in the $\mathrm{EtOH}$ group.

Table 1: Primers for CYP2E1, NADPH oxidase, IL-1 $\beta$ and TNF- $\alpha$

\begin{tabular}{|c|c|c|}
\hline \multirow{2}{*}{ CYP2E1 [11] } & Forward primer & 5'ACTTCTACCTGCTGAGCAC-3' \\
\hline & Reverse primer & 5'-TTCAGGTCTCATGAACGGG-3' \\
\hline \multirow[t]{2}{*}{ NADPH oxidase [12] } & Forward primer & 5'-GGAAATAGAAAGTTGACTGGCCC-3' \\
\hline & Reverse primer & 5'-GTATGAGTGCCATCCAGAGCAG-3' \\
\hline \multirow[t]{2}{*}{ IL-1 $\beta[13]$} & Forward primer & 5'-CCCTGCAGCTGGAGAGTGTGG-3' \\
\hline & Reverse primer & 5'-TGTGCTCTGCTTGAGAGGTGCT-3' \\
\hline \multirow[t]{2}{*}{ TNF- $\alpha[13]$} & Forward primer & 5'-GACCCTCACACTCAGATCATCTTCT-3' \\
\hline & Reverse primer & 5'-TGCTACGACGTGGGCTACG-3' \\
\hline$\beta$-actin [14] & $\begin{array}{l}\text { Forward primer } \\
\text { Reverse primer }\end{array}$ & $\begin{array}{l}\text { 5'-TTCTTTGCAGCTCCTTCGTTGCCG-3' } \\
\text { 5'-TGGATGGCTACGTACATGGCTGGG-3' }\end{array}$ \\
\hline
\end{tabular}


A

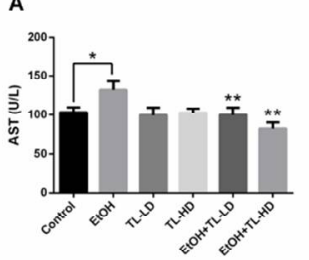

C
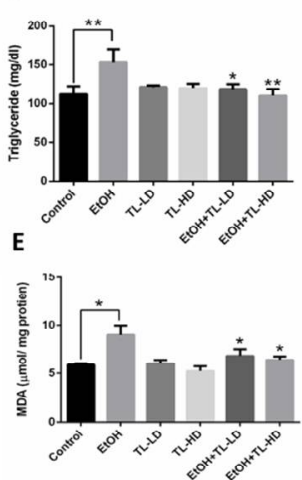

B
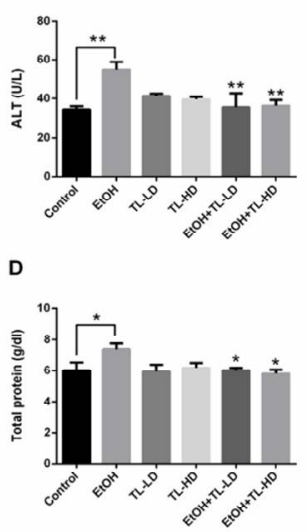

Figure 1: Effect of $T$. laurifolia aqueous leaf extract on liver enzymes, triglycerides, total protein and MDA levels. AST (A), ALT (B), triglycerides (C), total protein (D) and MDA (E) levels of rats in the control, $\mathrm{EtOH}, \mathrm{TL}-\mathrm{LD}, \mathrm{TL}-\mathrm{HD}, \mathrm{EtOH}+\mathrm{TL}-\mathrm{LD}$ and EtOH+TL-LD groups. Results are expressed as mean \pm SEM $(n=4$ per group). ${ }^{*} p<0.05 ;{ }^{* *} p<0.001$ )

\section{Effect of $T$. laurifolia aqueous leaf extract on histopathological changes in rat liver}

Liver tissue from rats in the control group showed normal histology (Figure 2 A). Moreover, liver tissue from rats in the TL-LD and TL-HD groups also had normal histology, indicating that 100 and $200 \mathrm{mg} / \mathrm{kg}$ of $T$. laurifolia leaf extract given once a day from weeks 5-10 did not produce hepatotoxic effects (Figure $2 \mathrm{C}$ and $\mathrm{D}$ ). The hepatocytes of rats in the $\mathrm{EtOH}$ group revealed cell death (Figure $2 \mathrm{~B}$ ). However, treatments with low dose (EtOH+TL-LD group) and high dose $(\mathrm{EtOH}+\mathrm{TL}-\mathrm{HD}$ group) of $T$. laurifolia leaf extract were able to mitigate alcohol-induced liver pathology, as shown in Figures $2 \mathrm{E}$ and $\mathrm{F}$.

\section{Effect of aqueous leaf extract of $T$. laurifolia on hepatic NADPH oxidase, CYP2E1, IL-1 $\beta$ and TNF- $\alpha$ gene expressions}

Rats in the $\mathrm{EtOH}$ group showed significantly upregulated gene expressions of hepatic CYP2E1, NADPH oxidase, IL-1 $\beta$ and TNF- $\alpha$, when compared to rats in the control group $(p<0.001)$ (Figure 3). In the high and low dose groups of $T$. laurifolia leaf extract $(\mathrm{EtOH}+\mathrm{TL}-\mathrm{LD}$ group and $\mathrm{EtOH}+\mathrm{TL}-\mathrm{HD}$ group), there were significant down-regulations of hepatic CYP2E1 gene expressions $(p<0.05)$, when compared to the control group (Figure $3 \mathrm{~A}$ ). Moreover, there was

significant down-regulation of hepatic NADPH oxidase gene expressions in these groups $(p<$ $0.05, p<0.001$, respectively), relative to the control group (Figure $3 \mathrm{~B}$ ). Rats in the $\mathrm{EtOH}+$ TL-LD group had significantly down-regulated gene expression of hepatic TNF- $\alpha(p<0.001)$, while rats in the EtOH + TL-HD group had significantly down-regulated gene expressions of hepatic IL-1 $\beta(p<0.05)$ and TNF- $\alpha(p<0.001)$, when compared to rats in the $\mathrm{EtOH}$ group (Figures $3 \mathrm{C}$ and $\mathrm{D}$ ). Thus, $T$. laurifolia leaf extract treatment down-regulated gene expressions of hepatic TNF- $\alpha$ and hepatic IL-1 $\beta$ in response to ethanol treatment.

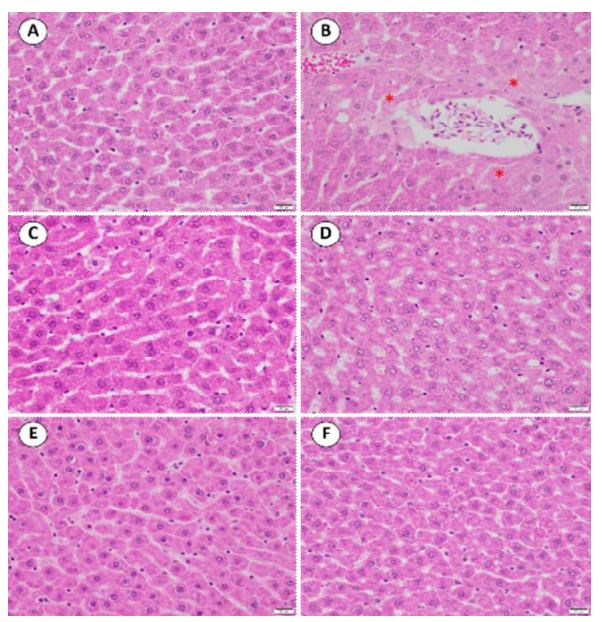

Figure 2: Effect of $T$. laurifolia aqueous leaf extract on liver histopathological changes. Control (A), EtOH (B), TL-LD (C), TL-HD (D), EtOH + TL-LD (E) and EtOH +

TL-LD (F) groups. The red asterisks indicate cell death. Scale bar $=20 \mu \mathrm{m}$ (H \& E staining)
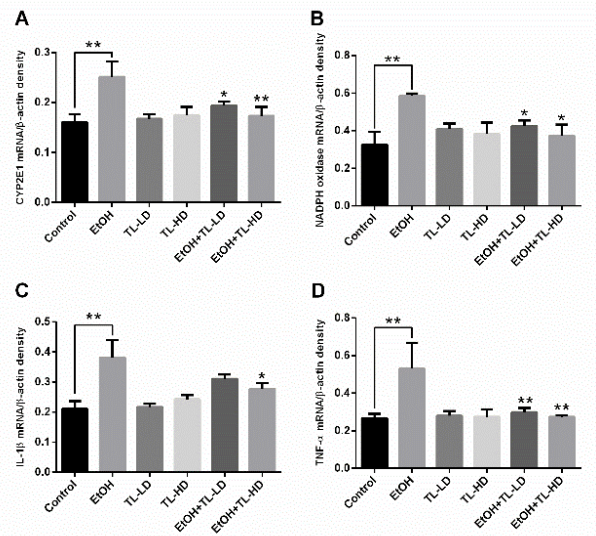

Figure 3: Effect of aqueous leaf extract of $T$. laurifolia on hepatic NADPH oxidase, CYP2E1, IL-1 $\beta$ and TNFa gene expressions. Gene expressions of hepatic NADPH oxidase (A), CYP2E1 (B), IL-1 1 (C) and TNFa (D) of control, EtOH, TL-LD, TL-HD, EtOH + TL-LD, and $\mathrm{EtOH}+\mathrm{TL}-\mathrm{LD}$ groups. Results are expressed as mean \pm SEM $(\mathrm{n}=4) ;{ }^{*} p<0.05 ;{ }^{* *} p<0.001$ 


\section{DISCUSSION}

Normally, serum ALT is considered a more specific biomarker of liver damage than serum AST, because ALT originates primarily from the hepatocytes, whereas AST is also found in extrahepatic tissues [15]. However, increased activities of blood liver enzymes do not necessarily reflect liver cell death [16]. This study has indicated that $T$. laurifolia leaf extract treatment did not induce liver damage. Rather, it normalized blood levels of AST, ALT, triglycerides and total protein in ethanol-treated rats. The effects of $T$. laurifolia leaf extract on ethanol-treated rats are similar to the effects observed with other herbal extract [17].

Oxidative stress is characterized by an imbalance between oxidants and antioxidants. Malondialdehyde (MDA) is a well-known biomarker of oxidative stress. An increase in ROS causes overproduction of MDA. In this study, ethanol increased MDA levels in rats. Interestingly, treatment with $T$. laurifolia leaf extract reversed the ethanol-induced increases in MDA levels. Thus, the antioxidant effect of $T$. laurifolia leaf extract reduces oxidative stress. From previous studies, high performance liquid chromatography analysis of aqueous leaf extract of $T$. laurifolia identified caffeic acid and apigenin as primary constituents, whereas the acetone and ethanol extracts contained primarily chlorophyll a and b, pheophorbide a, pheophytin a, and lutein. The antioxidant properties of plant extracts are due to their phytochemical constituents $[18,19]$.

The present study has demonstrated that ethanol up-regulated gene expressions of hepatic CYP2E1, NADPH oxidase, IL-1 $\beta$ and TNF- $\alpha$. It is known that CYP2E1 metabolizes ethanol and generates ROS. Moreover, CYP2E1 overexpression is increasingly recognized as a key factor in hepatic injury [20]. The downregulation of hepatic CYP2E1 gene expressions and alleviation of ethanol-induced liver damage by $T$. laurifolia leaf extract are similar to previous report [21]. Normally, NADPH oxidase is expressed in hepatocytes, hepatic stellate cells and Kupffer cells in the liver. It is involved in alcoholic liver injury as major source of ROS leading to oxidative stress [5]. In the present study, it was found that $T$. laurifolia leaf extracts at low dose and high dose down-regulated hepatic NADPH oxidase gene expression in response to ethanol intake in rats. Previous studies demonstrated that down-regulation of hepatic NADPH oxidase gene attenuated ALD $[5,22]$.
The pro-inflammatory cytokine IL-1 $\beta$ is upregulated in alcoholic liver disease [23]. Another pro-inflammatory cytokine is TNF- $\alpha$ is mainly produced by Kupffer cells in the liver. It is a key mediator in various physiological processes such as inflammation and apoptosis [24]. It has been reported that in alcoholic liver disease patients, the levels of TNF- $\alpha$ were increased, when compared with non-alcoholic fatty liver disease controls [25]. The present study has demonstrated that $T$. laurifolia leaf extract downregulated gene expressions of hepatic IL- $1 \beta$ and TNF- $\alpha$ in response to ethanol treatment. These results indicate that $T$. laurifolia possesses antiinflammatory properties in alcoholic liver injury related to other conditions [9].

\section{CONCLUSION}

These findings indicate that the aqueous leaf extract of $T$. laurifolia alleviates alcohol-induced liver injury in male Wistar rats. It does this through reduction in MDA levels, down-regulation of hepatic CYP2E1 and NADPH oxidase gene expressions, and down-regulation of the gene expressions of hepatic IL- $1 \beta$ and TNF- $\alpha$. Thus, the extract may potentially be suitable for the treatment of liver injury.

\section{DECLARATIONS}

\section{Acknowledgement}

This research was supported by a grant from the Institute of Research and Development (under contract WU59106), Walailak University, Thailand. We are thankful to the Dean and all staff of School of Medicine, Walailak University for their kind support.

\section{Conflict of Interest}

No conflict of interest associated with this work.

\section{Contribution of Authors}

The authors declare that this work was done by the authors named in this article and all liabilities pertaining to claims relating to the content of this article will be borne by them.

\section{Open Access}

This is an Open Access article that uses a funding model which does not charge readers or their institutions for access and distributed under the terms of the Creative Commons Attribution License (http://creativecommons.org/licenses/by/ 4.0) and the Budapest Open Access Initiative 
(http://www.budapestopenaccessinitiative.org/rea d), which permit unrestricted use, distribution, and reproduction in any medium, provided the original work is properly credited.

\section{REFERENCES}

1. Khalili M, Burman B. Liver Disease. In: Hammer $G D$, McPhee SJ, editors. Pathophysiology of Disease: An Introduction to Clinical Medicine, 7e. New York, NY: McGraw-Hill Education; 2013.

2. Magdaleno F, Blajszczak CC, Nieto N. Key Events Participating in the Pathogenesis of Alcoholic Liver Disease. Biomolecules 2017; 7: 9 .

3. Jiang JX, Torok NJ. NADPH Oxidases in Chronic Liver Diseases. Adv Hepatol 2014; Article ID 742931.

4. Leung TM, LU Y. Alcoholic liver disease: from CYP2E1 to CYP2A5. Curr Mol Pharmacol 2017; 10: 172-178.

5. Sasaki Y, Dehnad A, Fish S, Sato A, Jiang J, Tian J, Schröder $K$, Brandes R, Török NJ. NOX4 regulates CCR2 and CCL2 mRNA stability in alcoholic liver disease. Sci Rep 2017; 7: 46144.

6. Zeng $T$, Zhang $C L$, Xiao $M$, Yang R, Xie KQ. Critical roles of kupffer cells in the pathogenesis of alcoholic liver disease: from basic science to clinical trials. Front Immunol 2016; 7: 538.

7. Iracheta-Vellve A, Petrasek J, Gyogyosi B, Bala S, Csak $T$, Kodys K, Szabo G. Interleukin-1 inhibition facilitates recovery from liver injury and promotes regeneration of hepatocytes in alcoholic hepatitis in mice. Liver Int 2017; 37: 968-973.

8. Pramyothin $P$, Chirdchupunsare $H$, Rungsipipat $A$, Chaichantipyuth C. Hepatoprotective activity of Thunbergia laurifolia Linn extract in rats treated with ethanol: in vitro and in vivo studies. J Ethnopharmacol 2005; 102: 408-411.

9. Wonkchalee $O$, Boonmars T, Aromdee C, Laummaunwai $P$, Khunkitti $W$, Vaeteewoottacharn $K$, Sriraj $P$, Aukkanimart R, Loilome W, Chamgramol Y, Pairojkul C, Wu Z, Juasook A, Sudsarn P. Anti-inflammatory, antioxidant and hepatoprotective effects of Thunbergia laurifolia Linn. on experimental opisthorchiasis. Parasitol Res 2012; 111: 353-359.

10. National Research Council. Guide for the care and use of laboratory animals. 8th ed. The National Academies Press, Washington DC, USA, 2011; pp 1-23.

11. Man XB, Tang L, Qiu XH, Yang LQ, Cao HF, Wu MC, Wang HY. Expression of cytochrome P4502E1 gene in hepatocellular carcinoma. World J Gastroenterol 2004; 10: $1565-1568$

12. Rashed LA, Hashem RM, Soliman HM. Oxytocin inhibits NADPH oxidase and P38 MAPK in cisplatin-induced nephrotoxicity. Biomed Pharmacother 2011; 65: 474480.
13. You Z, Luo C, Zhang W, Chen Y, He J, Zhao Q, Zuo R, $W u Y$ Y. Pro- and anti-inflammatory cytokines expression in rat's brain and spleen exposed to chronic mild stress: involvement in depression. Behav Brain Res 2011; 225: 135-141.

14. Bessa SS, Mohamed Ali EM, Abd EI-Wahab Ael S, Nor El-Din SA. Heme oxygenase-1 mRNA expression in Egyptian patients with chronic liver disease. Hepat Mon 2012; 12: 278-285.

15. Niemelä O. Biomarker-Based Approaches for Assessing Alcohol Use Disorders. Int J Environ Res Public Health 2016; 13: 166.

16. Contreras-Zentella ML, Hernández-Muñoz R. Is liver enzyme release really associated with cell necrosis induced by oxidant stress? Oxid Med Cell Longev 2016; Article ID 3529149.

17. Bourogaa E, Jarraya RM, Nciri R, Damak M, Elfeki A. Protective effects of aqueous extract of Hammada scoparia against hepatotoxicity induced by ethanol in the rat. Toxicol Ind Health 2014; 30: 113-122.

18. Gülçin i. Antioxidant activity of caffeic acid (3,4dihydroxycinnamic acid). Toxicology 2006; 217: 213220.

19. Romanova D, Vachalkova A, Cipak L, Ovesna Z, Rauko $P$. Study of antioxidant effect of apigenin, luteolin and quercetin by DNA protective method. Neoplasma 2001; 48: 104-107.

20. Butura A, Nilsson K, Morgan K, French SW, Johansson I, Schuppe-Koistinen I, Ingelman-Sundberg M. The impact of CYP2E1 on the development of alcoholic liver disease as studied in a transgenic mouse model. $J$ Hepatol 2009; 50: 572-583.

21. Wang F, Liu JC, Zhou RJ, Zhao X, Liu M, Ye H, Xie ML. Apigenin protects against alcohol-induced liver injury in mice by regulating hepatic CYP2E1-mediated oxidative stress and PPAR alpha-mediated lipogenic gene expression. Chem Biol Interact 2017; 275: 171-177.

22. Sun $Q$, Zhang $W$, Zhong $W$, Sun $X$, Zhou $Z$. Pharmacological inhibition of NOX4 ameliorates alcoholinduced liver injury in mice through improving oxidative stress and mitochondrial function. Biochim Biophys Acta 2017; 1861: 2912-2921.

23. Mathews S, Gao B. Therapeutic potential of interleukin 1 inhibitors in the treatment of alcoholic liver disease. Hepatology 2013; 57: 2078-2080.

24. McClain CJ, Song Z, Barve SS, Hill DB, Deaciuc I. Recent advances in alcoholic liver disease. IV. Dysregulated cytokine metabolism in alcoholic liver disease. Am J Physiol Gastrointest Liver Physiol 2004; 287: G497-502.

25. Neuman MG, Maor $Y$, Nanau RM, Melzer E, Mell $H$, Opris M, Cohen L, Malnick S. Alcoholic liver disease: role of cytokines. Biomolecules 2015; 5: 2023-2034. 